\title{
A Social Movement Theory Typology of Militant Organisations: Contextualising Terrorism
}

\begin{abstract}
Typologies are ubiquitous in terrorism studies, illustrating their continued appeal as a tool to further our understanding of this form of political violence. Despite this, to date, the promise of an empirically derived typology has largely been neglected. In addressing this gap, this paper sets out a typology developed from Social Movement Theory. Using a novel statistical technique to derive a three-dimensional framework for categorising militant groups, the typology incorporates both organisational characteristics and the wider political context. The result is a typology defined by three conceptual constructs: political capacity, war-making capacity and network capacity. Alongside these organisational features, imposing measures of the wider political opportunity structure reveals eight types of militant organisation. To explore the utility of the framework, a preliminary analysis interprets the typology in light of the presence of wider conflict. That a robust relationship is found between the various types and whether groups were operating in peacetime, civil war, or low-intensity conflict, goes some way to demonstrating its utility as an analytical tool. Conclusions draw attention to the importance of contextualising militant groups in their sociopolitical setting, and the benefits of combining theory alongside empirical analysis to develop robust characterisations of violent organisations.
\end{abstract}

Keywords: Typology, Social Movement Theory, Multidimensional Partial Order Scalogram by Coordinates, mixed methods, conceptualising militant groups

\section{Introduction}

Terrorism studies has seen a range of efforts to portray complex ideas related to militancy and political violence, work that has seen scholars use an array of techniques to characterise their object of study. As part of this effort, dozens of typologies of terrorism have been developed, ${ }^{1}$ a fact that underpins the oft-quoted remark that there are as many typologies of terrorism as there are analysts. ${ }^{2}$ However to date, the promise of combining statistical analysis and typological development remains underexploited. In addressing this gap, this paper presents a statistically 
derived typology, developed from Social Movement Theory, which sets out the primary organisational and contextual features of a range of militant groups.

Classification systems have long been applied to order phenomena and develop our understanding about the natural and social worlds. Typologies have been used to classify everything from types of voter, and personality types, to forms of social mechanisms. ${ }^{3}$ Their ubiquity demonstrates that robust frameworks capable of encompassing theoretical, empirical, and philosophical components can aid knowledge development and generate new paths of thinking. As G. K. Roberts suggested, the utility of typologies can be interpreted according to their ability "to discover new relationships among things so ordered, to generate hypotheses, to lead on to the development of theories, and to identify areas for investigation". 4

Developed carefully, typologies are able to respond to a number of the criticisms made of the terrorism studies literature. Specifically, that much work in the field takes the group out of its context and interprets it in isolation, that it fails to apply theory and demands greater interdisciplinary work. ${ }^{5}$ In addition, failure to interrogate state behaviour, and a state-centric bias have been held up as criticisms. ${ }^{6}$ The typology presented in this paper responds to some of these challenges by exploring the promise of using Social Movement Theory (SMT) as the framework for a statistically derived typology of militant groups. By deriving a coding framework from two of the main struts of SMT - political opportunity structure and resource mobilisation - the typology incorporates both wider socio-political context and organisational characteristics. In doing so, it offers a more holistic account of militant groups than existing conceptualisations, and provides a more robust platform for further analysis.

The typology is developed using a novel statistical approach that combines quantitative and qualitative techniques. Taking a wide range of data on 28 dormant militant groups (the reason for selecting dormant groups is explained below), the technique of Multidimensional Partial Order Scalogram by Coordinates (MPOSAC) is used to compare and order their most discriminating characteristics, that is, those features that best define the groups. The result is a three-dimensional typology delineating the groups and the settings in which they operate. This represents one of only a handful of studies to use this technique to develop typology in the social 
sciences. Moreover, it is the first typology to employ SMT as an organising framework in terrorism studies, further deepening the conversation between the two fields. This exploratory study therefore examines the potential for MPOSAC to elucidate the characteristics of militant groups, placing them in their socio-political context through employing SMT as an organising framework.

The paper proceeds as follows, after a brief review of the place of typology and SMT in terrorism studies, the methods used to develop the typology are described, followed by the results of the analysis in the form of a three-dimensional typology of militant groups. Analysis reveals three main constructs that inform group structure: war-making capacity, network capacity and political capacity. These three features define eight types of organisation that use terrorism. Moreover, these types are closely related to particular forms of political opportunity structure, determined by levels of political stability and civil liberties/political rights.

To investigate the typology's utility to develop our understanding of terrorism and political violence, a preliminary exploration examines the relationship between the various types and the presence of wider conflict. Some striking regularities are revealed between the different types of group and the extent of civil war, lowintensity conflict, or circumstances best described as 'peacetime'. Discussion draws attention to the importance of placing groups firmly in their socio-political context, and the utility of novel statistical techniques, such as MPOSAC, to describe complex phenomena in a parsimonious way that facilitates further research and analysis. In particular, the development and analysis of the typology provides a robust empirical foundation from which to develop a wide number of hypotheses and research questions relating to ongoing debates in the field. For example, focusing on the sociopolitical context in which terrorism develops invites us to consider in more detail the ways in which democracy may inhibit or facilitate particular types of violence. Similarly, by looking across a range of different groups, hypotheses relating to how and why primarily political organisations make the move towards violence, or when nonviolent movements take up arms suggest themselves. Given the wide scope of organisations that use terrorism and political violence, the typology also invites us to consider more carefully what we mean by 'terrorist groups'. These are just some of 
the research directions the typology could usefully contribute to, underpinned by a concerted effort to understand terrorism in its socio-political context.

\section{Typologies in Terrorism Studies}

Done well, formal ways of analysing information, such as typologies, help provide discipline and allow for the ordering of data before it is taken forward for interpretation, discussion and narrative development. ${ }^{7}$ Because precisely the same phenomena do not recur in the social world, in order to develop better explanations, as McKinney suggested over forty years ago, it is helpful to "reduce the complex to the simple, the unique to the general, and the occurrent to the recurrent." ${ }^{8}$ Typology also allows the specification of types where an end state may be realised in a variety of ways, thereby helping to both describe and uncover equifinality. ${ }^{9}$ In turn, this helps to develop a better understanding of the different causal pathways that may lead to a given outcome.

A number of areas in the typological literature on terrorism and political violence invite further work. The first is to increase the use of empirical approaches to developing typologies. Of the current crop, relatively few typologies use an inductive, empirical route to formulate their conceptualisations. Most select a particular issue of interest to build their frameworks around, without incorporating empirical data to support their development. For example, one of the more innovative approaches to typologies in terrorism studies in recent years is that developed by Boaz Ganor, in the shape of a limiting variable typology. ${ }^{10}$ Classifying organisations by the variable that limits their activities, the typology delineates groups according to theu level of motivation and operational capability a group has at any given time. Where both these variables exceed the 'terror level threshold', terrorism is considered more likely to occur. One of the challenges this approach faces is justifying the reduction of the complex range of factors acting on groups into single variables such as motivation and operational capability. An empirical foundation supporting the subordinate factors likely to inform how these broader variables emerge would offer a robust response to this challenge.

More generally, terrorism studies has been criticised for neglecting the context in which campaigns develop and decline. ${ }^{11}$ Work is increasingly addressing this issue, 
for example, Khusrav Gaibulloev and Todd Sandler recently looked across factors internal to groups and base country characteristics to inform our understanding of how militant groups end. ${ }^{12}$ There is a need to replicate such efforts in typological work. Generally speaking, only those conceptualisations looking at state-, non-state relationships, such as Thornton's early efforts to distinguish between regime terror and agitational terror, incorporate the wider context into their conceptualisations. Arguably, it is at the intersection of the violent group, the ruling power, and the people, that the success or failure of the group is decided. Incorporating these aspects more systematically into typology development therefore seems a helpful way of further developing our understanding of terrorism.

Although some work has considered the group's position in the wider political setting, they can often be at a high level of abstraction making it less easy to see how they further our understanding of particular groups. For example, Lizardo and Bergesen's conceptualisation characterises groups by their situation in the world system, described as either embedded in the structural core, on its periphery, or inbetween, in the semi-periphery, thereby specifying a number of actor-target dyads. ${ }^{13}$ These categories are set alongside ideological justification, delineated according to historical period echoing Rapoport's four waves thesis. ${ }^{14}$ The outcome is a typology of three types: 'terror in the core', where popular violence or revolt is carried out in core states; 'struggling against oppression' which sees the greatest use of terrorism; and 'the transnational turn' which involves groups in the semi-periphery attacking core targets across international borders. Such typologies helpfully position political actors in a sweep of relations with the state or opposition group. Conceptually, they operate on a broad scale and are useful from a legal and political perspective in delineating actors, jurisdictions and levels of proscription. However, they neglect the characteristics of these groups, focusing largely on their relations with wider power structures. A more inclusive approach incorporating both group-state interaction and organisational characteristics offers the promise of a more holistic basis from which to develop our understanding of terrorism.

Perhaps however, such critique is unfair, typologies are by definition a simplification, selectively identifying factors believed to be important in furthering our understanding of a particular phenomenon. However, this discussion does raise 
the important question of how best to select the variables we incorporate into typologies. One way of responding to this challenge is exploring what is to be gained by using theory as a starting point. Theory offers a way of identifying and organising important characteristics, relating them to causal relationships, and linking multiple factors at different levels of analysis. ${ }^{15}$ Thus far, typological work has perhaps not taken full advantage of the opportunities theory offers in this regard. As the following discussion sets out, SMT is well placed to facilitate this effort in terrorism studies.

\section{Social Movement Theory}

Social movements have been defined as "collective challenges, based on common purposes and social solidarities, in sustained interaction with elites, opponents, and authorities." ${ }^{16}$ Sometimes considered under the wider rubric of contentious politics, SMT analyses social movements via a tripartite framework, incorporating mobilising resources, political opportunities, and framing. ${ }^{17}$ Charles Tilly described SMT as "an orienting device for the sorting of observations", ${ }^{18}$ and it is primarily in this context that it is used in this study. Indeed, this endeavour of describing and categorising movement characteristics has been described as a particularly important feature of understanding collective action, as Smelser said: "[b]efore we can pose questions of explanation, we must be aware of the character of the phenomena we wish to explain." 19

Although previously neglected in the terrorism field, SMT is increasingly being applied in this area. ${ }^{20}$ Described as "one of the most consistent attempts to devise a more neutral, objective set of theoretical tools to analyse [movements], SMT is particularly helpful in its focus on the interaction between the state and the group. ${ }^{22}$ Further, as it incorporates micro, meso and macro levels of analysis, SMT is an ideal theoretical framework for contextualising terrorism and political violence in its socio-political setting. ${ }^{23}$ These features make it an ideal candidate to guide typological development as Donatella della Porta suggests:

Not only do underground organizations differ according to their goals, they also have varying organizational models and favor different forms of action. Any attempt to develop interpretative hypotheses about 'terrorism' is therefore 
destined to fail without a typology that can identify their range of application. $^{24}$

\section{Methodology}

Developing the typology involved first constructing a coding framework, drawing out the core features of SMT. This guided the content analysis of secondary data on 28 dormant groups, a process that converted qualitative data into quantitative measures, representing the presence, absence or intensity of the SMT-derived variables. These data were analysed using the MPOSAC procedure to produce the typology, what follows sets out the various stages of the process in more detail.

\section{Social Movement Theory Coding Framework}

The basis of the coding framework drew on two of SMT's three component elements: resource mobilisation and political opportunity structure, ${ }^{25}$ the third element, framing, is concerned with the discursive way groups frame their message, and is hence less suited to strict categorisation and quantitative analysis. Broadly described, mobilising resources are those things which allow the mobilisation and operationalisation of collective action, such as finance and personnel. These combine with political opportunities to provide the circumstances within which social movements emerge and function. In developing the coding protocol, two comprehensive frameworks offering detailed accounts of these two constructs were identified in the literature: Edwards and McCarthy's conceptualisation of resource mobilisation ${ }^{26}$ and Kriesi's framework of political opportunity structures ${ }^{27}$ alongside McCarthy's identification of core areas of research. ${ }^{28}$

Resource mobilisation: Edwards and McCarthy's framework is made up of four elements. The first are the types of resources to be mobilised, divided into five elements: moral, cultural, social-organisational, human and material. The second feature of the framework is the utility of these resources. Thirdly, mechanisms of resource mobilisation, described by four categories: movement self-production, where they generate the resource themselves; aggregation of many people's resources; appropriation or co-option involving the legitimate borrowing, or exploitation of another's resources; and finally patronage, where resources are gifted by a benefactor. Finally, four processes of resource mobilisation are considered, looking at 
the ways in which resources, once accessed, are put into practice. This focuses on the mobilisation of finance and personnel, both of which are influenced by the development of an organisation or movement structure, and finally, creating resources and mobilisation through collective action. ${ }^{29}$

Table 1 illustrates the main features of the framework selected for use in this study, along with specific indicators adapted for application to groups that use terrorism. It utilises two of the four aspects of Edwards and McCarthy's framework: the types of resources, and the mechanisms or resource mobilisation, the other two elements - utility and processes - focus on the implementation and effects of resource mobilisation. Whilst these are important, for the purposes of the typology, attention is focused on the nature of the resources rather than their impact. Importantly, the framework evolved over the course of data collection in response to the availability of reliable data and its relevance to militant groups. By doing this, it was possible to reach a better representation of groups for the purposes of comparative analysis. In addition, it allowed the framework to evolve, to offer a better fit between the theoretical framework and its application to groups that use terrorism.

- Table 1 about here -

Political opportunities: Political opportunities were interpreted in light of Kriesi's framework, a flexible conceptualisation made up of three broad themes constituting sets of variables: structures, configurations of power, and interaction contexts. ${ }^{30}$ From this range of factors, a specific 'political opportunity set' was developed informed by previous work on terrorism and social movements ${ }^{31}$ and McCarthy's discussion of the most important features of political opportunity structures. ${ }^{32}$ Hence, three sets of variables were isolated: the relative openness of the institutionalised political system assessed through political rights; the degree of stability illustrated by the broad set of elite alignments; and the way in which the state engages with challengers, analysed via measures of civil liberties.

Group selection: One of the issues typologies of terrorism face is that of 'freezing' complex, dynamic social phenomena. ${ }^{33}$ To address this challenge, dormant groups were selected, a choice which made it possible to determine the most characteristic measure of the group over its lifetime. Two major studies that examined a large 
number of violent groups were used to identify suitable groups: Audrey Kurth Cronin's study, How Terrorism Ends, ${ }^{34}$ which looked at 457 groups, and Jones and Libicki's, How Terrorist Groups End, ${ }^{35}$ that examined 648 militant organisations. Taking the groups identified as having ceased operations in these two studies as a starting point, a number of further decision criteria were used to make the final selection:

1. Groups which had re-emerged or continued violent operations were excluded;

2. Groups which ended pre-1997 were excluded (as some data used to build the typology is not available pre-1997);

3. These groups were cross-referenced with GTD and RAND databases to assess the number of attacks for which they were held responsible. Where there was no data in either database about the group, or where both agreed there was no sustained campaign ${ }^{36}$ they were excluded; and

4. Finally, to ensure there was sufficient data on which to draw, the remaining groups were cross-referenced with Jane's World of Insurgency and Terrorism - the primary source for the content analysis - where no profile was found, they were excluded. ${ }^{37}$

The result of this process resulted in 28 groups going forward for analysis. This comparatively small number can be attributed to two major factors; first, most of the groups in Kurth Cronin and Jones and Libicki's analyses were still active or had splintered into factions - identifying those groups that had ceased operations post1997 discounted 551 of those groups in Jones and Libicki's study, and 375 from Kurth Cronin's sample. Second, in looking for groups responsible for a sustained campaign of violence and those listed in major databases, less robust groups were excluded from the analysis, discounting around 50 groups from each sample. Although the resulting sample is small, the way it was derived suggests it is representative of those groups which ended operations in the relevant time period and which demonstrated the capacity for sustained violence. However, given that group selection began with existing databases, it is to some degree determined by the broader definitions of terrorism applied in the field. The result is a somewhat heterogeneous selection of organisations. What they have in common is having desisted from the sustained use of terrorism in recent years. As such the typology is as 
much a reflection of common interpretations and definitions of terrorism as it is on the characteristics of the particular groups it is concerned with.

Source data and coding: The content analysis for the mobilisation variables was guided by a set of definitions derived from the literature. Specifically, the SMT literature informed development of the mobilisation variables, whilst Louise Richardson's scale of state-sponsorship guided coding for this measure. ${ }^{38}$ Political rights and civil liberties were assessed using Freedom House measures, ${ }^{39}$ whilst World Bank measures of political stability were used. ${ }^{40}$ The mobilisation variables were coded using qualitative data, relying in the first instance on information derived from Jane's World Insurgency and Terrorism, and triangulated using data from additional secondary sources demonstrating in-depth knowledge of the groups. ${ }^{41}$ These data were analysed to assess the relative presence, absence and intensity of variables exhibited by particular groups.

To test the reliability of the coding carried out by the primary researcher, $25 \%$ of the data (equating to analysis of seven groups) was assessed by a second researcher with experience in qualitative data analysis. The percentage agreement between the raters was 92\% whilst the inter-rater reliability analysed using Spearman's rank order correlation was found to be $.95(\mathrm{p}<.01)$, a high level of agreement, suggesting the coding definitions and data used in the analysis facilitated reliable, consistent results.

Typology Development: Multidimensional Partial Order Scalogram by Coordinates: MPOSAC ${ }^{42}$ is a multivariate technique that allows the comparative analysis of a number of variables displayed by a range of subjects - in this case, militant groups to be displayed in geometric space. ${ }^{43}$ These variables must exhibit a common range, that is, a scale where all the items are ordered in a particular direction, guided by a common meaning. ${ }^{44}$ Meaning is derived from the theoretical foundation for the study, it precedes measurement and guides variable selection and research design. In this case, the common range is defined as the level of resource mobilisation exhibited by the groups. Hence, mobilisation variables were coded in the same direction - higher scores representing greater levels of mobilisation. The political opportunity measures on the other hand, were incorporated as external variables superimposed on the array.

Each group has a particular profile of responses, made up of a score on each variable, known as a structuple, displayed in Table $2 .{ }^{45}$ Through the MPOSAC 
procedure, these structuples are ordered according to their scores, in this case the range of scores runs from the lowest mobilisation score of 111111111, to the highest of 433333334. Where one group is quantitatively higher on the resource mobilisation measures than another, they can easily be ranked and their relationship displayed. For example 3222222223 is lower across all the measures, than 433333334 and hence would appear 'lower' in the array; these are described as comparable profiles. However, where they are qualitatively different - for example 1222222221 compared with 211111112 - they can only be organised according to a 'partial order', and are described as incomparable profiles. In these cases, an algorithm calculates the position in geometric space that offers the 'best fit' between all the profiles. Based on the scores across all of the variables, the algorithm positions the groups so that those that are more similar appear closer together, and those that are less similar appear further apart.

The MPOSAC technique therefore produces a graphical output displaying the position of the groups, in relation to one another according to their profiles on the range of resource mobilisation variables. ${ }^{46}$ Therefore it is the relationship between the different groups' scores across all of the resource mobilisation variables that determines their position in the graphical representation of the data. As Sabbagh, Cohen \& Levy explain:

POSAC is capable of revealing a typology of response styles ... because it focuses on the nature of relationships among groups of individual subjects rather than on relationships among variables (as in multidimensional scaling or factor analysis) or on magnitudes of isolated variables (e.g. degree of endorsement of equality or effort). ${ }^{47}$

After developing the scalogram using the resource mobilisation variables, the next stage in the analysis is to introduce the political opportunity measures onto the plot as external variables. This makes it possible to observe the relationship between the groups, arranged with respect to their levels of mobilisation, alongside superimposed measures of political stability and civil liberties; the interpretation of this array constitutes the typology. MPOSAC therefore portrays "multiple comparisons of respondents' profiles simultaneously, and [allows detection of] structural patterns among the profiles."48 
As well as the scalogram displaying the position of the groups according to how they relate to one another on the different variables, MPOSAC produces 'item diagrams' for each of the variables. These display the same array of points in the same place, but specify the score each group received on each of the variables, making it possible to see how the scores on the different measures partition the space. Ideally each variable should run from high to low on each measure such that the item diagram can be partitioned into regions containing a single score. In practice, as in this study, there are often deviations, a limited number of which are acceptable. ${ }^{49}$ The interpretation of these item diagrams forms the foundation of the typology, to which we now turn.

- Table 2 about here -

- Figure 1 about here -

\section{Results}

Because results are based on the analysis of a range of important variables in relation to one another, rather than correlating individual variables, MPOSAC makes it possible to identify the most discriminate features of the groups. ${ }^{50}$ This helps to identify the 'conceptual constructs' that underpin the phenomenon of interest. In interpreting Figure 1, it is helpful to note that each point represents a group, and that the position of the group is defined by its profile on a range of variables assessing their level of resource mobilisation. The closer together they appear, the more they have in common, and vice versa, whilst the highest possible score on all resource mobilisation variables is represented in the far right of the array, by the number 1, and the lowest in the bottom left, by the number 29, the line between these two points is the 'joint direction of the partial order'. ${ }^{51}$ All groups with comparable profiles are aligned in this direction. The objective is therefore to interpret the plot in a way which makes it possible to explain why particular groups cluster together, or fall further apart, based on their position relative to these two extremes of mobilisation. ${ }^{52}$

\section{Examining the Inter-correlations Between Variables}

Inspecting the correlations between the scalogram and the various mobilisation items presented in Table 3 demonstrates that several items correlate strongly with each of the axes: pre-existing fighters with axis 1; other group support with axis 2 ; and 
official wing with axis 3 . These are therefore the most discriminating variables, and help to define the position of the groups. However, the table also demonstrates that a number of other variables correlate strongly with the axes. Hence, state support, territory, and membership correlate with Axis 1, develop networks with Axis 2, and popular support, and training with Axis 3. It appears therefore, that three primary factors help define the groups:

1. War-making capacity: state support, territory, pre-existing fighters, membership.

2. Network capacity: other group support, develop networks.

3. Political capacity: official wing, training, popular support.

- Table 3 about here -

\section{Interpreting the Typology}

The partitions represented by the three most discriminate variables are an important vehicle for developing the typology, indeed, other analyses using this approach have relied solely on the most discriminating features to construct a typology. ${ }^{53}$ However, it is important to bear in mind that this approach does not just express the relationship between three items, rather, it displays the relationship amongst all of the variables. To interpret the typology and exploit the full potential of the MPOSAC approach, it is necessary to take all the mobilisation variables and the political opportunity external variables into account. By looking at the way the groups align in Figure 1, alongside the data in Table 2, and the item diagrams of each of the variables it therefore becomes possible to identify the conceptual constructs that underpin the SMT typology. The outcome of this analysis is displayed in Figure 2 and illustrates the eight types that make up the typology and the groups that fall within their scope.

- Figure 2 about here -

Each of the types identified by numbers 1-8 correspond to low or high scores on the three sets of variables. Hence, Figure 2 illustrates Axis 1 (war-making capacity) vs. Axis 2 (network capacity) vs. Axis 3 (political capacity). For ease of interpretation, the groups are listed according to their scores on the external political opportunity variables. ${ }^{54}$ Only one group from the 28 organisations demonstrates a profile characterised by limited networks and war-making capacity, but substantial 
political infrastructure, with Muttahida Qaumi Movement (MQM) located in type 1. Reflecting the fact that MQM were and remain primarily a political movement that has been intermittently implicated in violence and rioting, we see little in the way of infrastructure relating to militant training or territorial control; we can perhaps name this type 'agitators'.

In type 2, we can see a cluster of groups illustrating external networks of relatively limited scope, high levels of war-making and political capacity, whilst operating in an environment characterised by generally low levels of civil liberties and political stability; these can be categorised as 'armed movements'. To take an example, Polisario was relatively self-sustaining, relying on few external militant networks for support. At the same time, they were able to mobilise comparatively large numbers of members and hold territory as a legacy of the peace agreement brokered by the United Nations in the 1990s and the declaration of the Saharawi Arab Democratic Republic the previous decade. ${ }^{55}$

Type 3 contains three groups with similarly limited external networks, and low levels of political capacity, although more substantial war-making potential, notably experienced cadre and some territorial control; these are perhaps best described as 'armed vanguards'. In common with type 2 , these groups generally operate in areas of low political stability and civil liberties. In the case of the Aden Abyan Islamic Army, based in Yemen, they had the benefit of a number of experienced fighters derived from returnees from the Afghan-Soviet war, whilst the unstable political situation in the country meant they were able to operate in areas that lacked substantial state control. ${ }^{56}$

Type 4 includes groups with the lowest level of all three of our main resource mobilisation measures; groups here are best classified as 'revolutionary cells'. Interestingly, the political context these groups operated in was characterised by higher levels of political freedom and civil liberties, in contrast to the other types at the 'front' of the typology. Here we see groups based in Spain (1 October) and Northern Ireland (Loyalist Volunteer Force) - countries which are perhaps better equipped to limit the large-scale mobilisation of militant organisations, reflecting their limited numbers and levels of support. 
The types at the rear of the display are characterised by well-developed external networks, generally offering practical or logistical support, as well as gaining support from other militant groups. Beyond this main feature, these four types are delineated by the extent of their political and war-making capacity. Hence, type 5 includes groups demonstrating comparatively limited capacity for violence, but more substantial political infrastructure. In particular, these organisations have an official wing, and comparatively good levels of popular support; they might usefully be described as 'political partisans'. With respect to their political operating environment, they are drawn from countries characterised by mid or mid-high levels of political stability and civil liberties. For instance, Kach, the Israeli far-right group led by Rabbi Meir Kahane was, for a time, an official political party with Knesset representation. Although members did use violence, this reflected relatively limited coordination and planning, and there was no well organised armed militia that carried out a concerted campaign of violence alongside official party politics. ${ }^{57}$

Type 6 reflects low/mid-levels of political stability and civil liberties, including countries such as Angola and Sierra Leone. This type also represents the most highly mobilised of all the groups in the sample, demonstrating substantial warmaking capacity in the form of territory, and membership often into the tens of thousands; these are recognisably 'guerrilla armies'. For example, the Communist Party of Nepal-Maoist was reported to have up to 5,000 combatants, and a militia of up to $20,000 .^{58}$ Groups in this type are also often in receipt of state support, as well as demonstrating official representation and generally high levels of public support. Although, the RUF is an exception to this last measure, a fact which helps explain why in the original display, it is somewhat removed from the other groups in this type.

In contrast to type 6, type 7 has lower levels of political capacity and midhigh levels of war-making capacity, in particular in the shape of cadre with previous fighting experience. For example, the Abu Nidal Organisation (ANO) benefitted from membership drawn from Palestinian militant organisations and both ANO and the Groupe Islamique Armé (GIA) developed international networks - criminal and militant - to support their operations. These groups are also characterised by a political context with largely low levels of political stability and civil liberties; these 
can be classified as 'assisted vanguards'. Finally, type 8 demonstrates low levels of political and war-making capacity, but similar to type 4, are based in countries with generally high levels of political stability and rights such as Northern Ireland, Greece and Japan. These groups have no official political representation, hold no territory and have comparatively few members; they are perhaps best described as 'coordinated revolutionaries'.

Not all of the clusters demonstrate uniform levels of political rights and political stability, nor would we necessarily expect them to, given the range of countries and contexts included in the sample. However, it is possible to discern some general trends. Looking at Axis 1 vs. Axis 3, it becomes clear that the majority of groups in the right of the typology (denoting greater levels of war-making capacity: types 2, 3, 6 and 7) are located in countries with generally low levels of political stability and similarly low levels of civil liberties. Whereas, those in the bottom left quadrant of the scalogram (marking groups with low levels of political and warmaking capacity: types 4 and 8) are based in contexts marked by high levels of political stability and rights. The top left quadrant is the least uniform of the regions, showing no strong pattern with respect to political context.

In summary, the foregoing has established that the three axes representing three clusters of resource mobilisation measures helpfully define the position of the groups in the array. The typology not only sets out this information in a more interpretable manner than for example a table such as Table 2, it also illustrates how these variables relate to one another. More than this, the typology reveals an interesting relationship between levels of resource mobilisation and political opportunity structure. This seems to suggest a relationship between the scale and scope of groups and their operating environment - a finding that would be worth pursuing further. Indeed, the typology invites us to consider a range of research questions, and there is much that could be done with the framework as it stands. To demonstrate its potential, a short example of how the typology may be explored follows. 


\section{Placing Terrorism in Context}

The typology contributes to our understanding in a number of different ways. For those interested in the organisational make-up of militant groups, developing the typology has demonstrated empirically that three main constructs inform group structure. Further, the different types informed by these organisational characteristics seem to be related to the type of political system the groups are operating within. More generally, the analysis illustrated the utility of a novel approach to identifying regularities in complex data that is virtually unique to this method of analysis. Moreover, it is the first attempt at using such a technique to examine militant groups, and offers a way forward to further analysis.

A final advantage of this approach is that it takes into account both the group, and the political context within which it was operating. Not only does this invite us to consider what impact this may have on the evolution and decline of the group, it also serves as a reminder to consider the presence of wider conflict. The Correlates of War (COW) dataset provides a helpful starting point for exploring this idea further. ${ }^{59} \mathrm{By}$ examining the COW data on intra-state war, it is possible to identify a relatively robust relationship between the presence of civil war and a number of the types identified in the typology, illustrated in Table 4 . All of those groups in sections 2 (armed movements) and 6 (guerrilla armies) of the typology were involved in intrastate war or high-intensity civil conflict. With one exception, there is similar consistency in types 4 (revolutionary cells) and 8 (coordinated revolutionaries), which all operated in contexts largely free of wider political conflict. To capture the presence of conflict that fell between these two extremes, it is instructive to utilise the concept of 'low intensity conflict', defined as:

$[\mathrm{P}]$ olitical-military confrontation between contending states or groups below conventional wars and above the routine, peaceful competition among states. It frequently involves protracted struggles of competing principles and ideologies. Low intensity conflict ranges from subversion to the use of armed force. ${ }^{60}$

Although this is a relatively broad term, and whilst there are substantial divergences over how best to conceptualise this type of conflict in the literature, the notion of low intensity conflict does seem to adequately represent those conflicts with which all but 
two groups in sections 1 (agitators), 3 (armed vanguards), 5 (political partisans) and 7 (assisted vanguards) were involved.

Interestingly, this typology provides empirical support for Stepanova's functional typology of terrorism. ${ }^{61}$ She delineated the scale of a group's goals and the degree to which terrorism is related to a wider armed conflict, setting out three types of terrorism: 1) the 'classic' terrorism of peacetime, which, regardless of the group's goals, stands apart from wider conflict; 2) 'conflict-related terrorism', where terrorism is used along with other violent tactics as part of a broader asymmetrical or regional conflict, for example in Kashmir or Palestine; and 3) 'superterrorism' - global terrorism with existential, unlimited goals and motivations, epitomised by al-Qaeda.

Two of these three aspects are present in this study's typology. The first 'classic' terrorism of peacetime clearly relates to the bottom left section of the framework, where a number of left-wing groups using terrorism aside from any wider armed confrontation are situated, alongside smaller groups involved with the Northern Ireland conflict. The top right section of the typology tallies with Stepanova's conflict-related terrorism, as most of these took place in the context of a wider conflict, be that the fight for an independent Kurdistan; the wars in Angola and Sierra Leone; the conflict in Kosovo; or the insurgency in Nepal. However, there are no groups which exclusively represent 'superterrorism'. ${ }^{62}$ As al-Qaeda and its affiliates were not included in the analysis that generated the typology, this conceptualisation neglects al-Qaeda's particular organisational form, context and strategy. However, given that MPOSAC is designed to identify particular aspects of the entire 'content universe' of possible observations, it is possible to widen the scope of investigation to include these groups at a later date.

Beyond these two categories of peacetime and conflict-related terrorism, the bottom right and top left aspects of the typology mainly depict groups which used terrorism in the context of national liberation struggles and ethnic conflict. Here, low intensity conflicts associated with the disputes in Kashmir, Israel-Palestine, and a range of ethnic, religious and left-wing inspired confrontations in India, Pakistan, Thailand, Burma, Yemen and Nicaragua are represented. The typology therefore sets the use of terrorism firmly in the context of other forms of political violence and contestation. Identifying how terrorism relates to its historical and socio-political 
context in this way helps avoid the path to exceptionalism the study of terrorism has sometimes been accused of.$^{63}$ Instead, the typology cements terrorism as a tactic used in all types of conflict, from civil wars, liberation movements and smaller-scale causes. Not a new idea, but certainly a benefit of this approach.

The continuum of mobilisation represented in the typology allows for dynamic changes in violent mobilisation and levels of support. Clearly not uni-directional, this puts terrorism in a spectrum of violent actors from small, clandestine groups, to largescale insurgencies. After Bjørgo, the typology supports the idea that "there is not one 'terrorism' but several 'terrorisms'. [Hence] there are different types of terrorism with highly disparate foundations." ${ }^{64}$ Further, in this sample different levels of mobilisation appear in particular political contexts at different rates. Hence, in states with low levels of political freedom and stability, terrorism is more often found alongside other forms of political violence in the context of wider conflict, enacted by larger groups, akin to guerrilla armies. Whereas in politically free settings, smaller groups use terrorism against the state in settings best characterised as peacetime (although the INLA would probably have rejected this designation).

\section{Discussion}

This paper has addressed a number of issues. First, it has illustrated the utility of SMT as a way of organising qualitative data in a way that makes it suitable for quantitative analysis. Second, it has demonstrated a novel approach to developing typologies using MPOSAC; that some useful and interesting regularities have been identified in such noisy data is testament to its ability to disentangle complex phenomena. Further, the typology's ability to incorporate questions of organisational structure, political context and levels of wider conflict, speaks to its capacity to parsimoniously describe a range of different types of groups.

In assessing the utility of the typology, it is useful to return to the criteria set out by G. K. Roberts described in the first part of the paper, that is, considering whether it is able to facilitate the discovery of relationships, generate hypotheses, inform the development of theories, and identify areas for investigation. By these criteria, the typology appears to have fared reasonably well. Defined by three clusters of variables relating to different aspects of resource mobilisation, the typology illustrates an interesting relationship to levels of civil liberties and political stability, 
with groups characterised by high levels of resource mobilisation generally found in contexts of low political rights and stability. It also prompted questions about the scope of wider conflict, and its relationship to levels of mobilisation and particular political opportunity structures. Even this brief exploration of the typology demonstrated some interesting relationships between the type of group and the extent of conflict they were engaged in. As the typology was underpinned by an existing theory, its potential perhaps lies in the testing and evolution of SMT, rather than in developing theory per se. Nevertheless, it has demonstrated the utility of combining typological development and SMT via empirical analysis as a platform for further enquiry. More generally, the typology underlines that in order to understand terrorism and political violence, it is important to begin with an appreciation of the setting within which terrorism is used.

The typology also demonstrates why there have been such divergent conclusions about terrorism, for example, whether democracy inhibits or facilitates terrorism, ${ }^{65}$ or whether or not it is successful at achieving political goals. ${ }^{66}$ Comparing very different groups without taking into account their levels of mobilisation and the political opportunity structure they are operating in, leaves analysts comparing guerrilla armies with very small, clandestine groups. This puts too great a weight on group selection, and arguably does not offer much analytical clarity over terrorism in comparative context.

Moreover, the typology provides a basis for comparative analysis, as it makes it possible to parsimoniously identify those features groups have in common, and on which they differ. Finally, using the typology invites us to consider which features of groups to focus on when setting out to explain specific questions related to terrorism. For example, to some extent, the opportunities for opponents to degrade violent groups are determined by the organisational form and political context within which they are operating. Hence, groups with mid-levels of political capacity, but high levels of network development may be degraded by attacks on a group's official wing, or its training facilities, but are unlikely to be destroyed if they can rely on the support of other groups via substantial external networks. Similarly, attacking such external networks is unlikely to be effective if the group has substantial war-making capacity, such as state support. 
Taking into account the varying organisational forms represented in these types, this analysis further suggests we need to be more critical of the notion of 'groups' and their effects on terrorism - an argument which is beginning to be explored in the field. ${ }^{67}$ Some of the organisations considered in this analysis are best described as guerrilla armies, others only small cells, whilst others are often far more loosely connected, or represent umbrella organisations of groups or individuals with shared interests. This serves as a reminder that the stereotype of the 'terrorist group' is perhaps as much a product of wider discourses as it is a feature of reality.

As such, it is important to remain mindful that the typology is building on existing, Western databases, which have effectively compartmentalised one particular tactic used in a huge range of settings, by diverse actors, and reflected that concept back on to the groups to act as a defining marker. Using these databases is something of a necessary evil in comparative work. However, by exploring the characteristics of the 'groups' and their political settings, the typology draws out some of the complexity inherent in interpreting and understanding those who use it. It also offers an opportunity to reflect more critically on how we categorise militant actors.

Many of these points have been made in the literature before, however, by carefully aggregating the knowledge base into an intelligible framework, new opportunities for research have presented themselves. Through this process, this paper has responded to a number of issues in the literature, including reflecting on how to incorporate terrorism into wider accounts of political violence. It has also sought to address the charge that analysis of terrorism frequently fails to take account of the socio-political context in which violence takes place, can neglect the advantages of theory, and sometimes unnecessarily ignores relevant levels of analysis. Such differences in the literature point to the difficulty and complexity of researching terrorism, but also highlight the need for conceptual clarity and careful analysis. The foregoing represents an empirically founded framework from which to continue the exploration of the political and organisational manifestations of terrorism.

\footnotetext{
${ }^{1}$ For a recent review of terrorism typologies see: Sarah V. Marsden and Alex P. Schmid, "Typologies of Terrorism," in The Routledge Handbook of Terrorism Research, ed. Alex P. Schmid, (Chippenham: Routledge, 2011), 158-200.

${ }^{2}$ Chalmers Johnson, "Perspectives on Terrorism," in The Terrorism Reader, ed. Walter Laqueur, (New York: American Library, 1978), 276.
} 
${ }^{3}$ Pew Research Center, Beyond Red vs. Blue: The Political Typology, 2011. Accessed 23 January, 2014: http://www.people-press.org/files/legacy-pdf/Beyond-Red-vs-Blue-The-Political-Typology.pdf; Isabelle Briggs Myers, Mary H. McCaulley, Naomi L.Quenk and Allen L. Hammer, MBTI Manual: A Guide to the Development and use of the Myers Briggs Type Indicator, 3rd ed. (Palo Alto, CA: Consulting Psychologists Press, 1998); Peter Hedstrom and Richard Swedberg, "Social Mechanisms," Acta Sociologica 39 no. 3 (1996): 281-308. doi: 10.1177/000169939603900302.

${ }^{4}$ Geoffrey K. Roberts, (1971). A Dictionary of Political Analysis (London: Longman, 1971), 216.

${ }^{5}$ Jeroen Gunning, "A Case for Critical Terrorism Studies," Government and Opposition 42 no. 3 (2007): 366-7. doi: 10.1111/j.1477-7053.2007.00228.x; Richard Jackson, "Critical Terrorism Studies: An Explanation, a Defence and a Way Forward." (Paper presented at International Studies Association Annual Conference, New Orleans, 20 February, 2010). Accessed 23 January, 2013:

http://citation.allacademic.com/meta/p_mla_apa_research_citation/4/1/3/3/7/pages413378/p4133781.php, 6.

${ }^{6}$ Harmonie Toros and Jeroen Gunning, "Exploring a Critical Theory Approach to Terrorism Studies," in Critical Terrorism Studies: A New Research Agenda, ed. Richard Jackson, Marie Breen Smyth and Jeroen Gunning (Oxon: Routledge, 2009), 94.

${ }^{7}$ Charles Tilly, (2004). "Observations of Social Processes and Their Formal Representations," Sociological Theory, 22 no. 4 (2004), doi: 10.1111/j.0735-2751.2004.00235.x, 596-8.

${ }^{8}$ John C. McKinney, Constructive Typology and Social Theory. (New York: Meredith Publishing Company, 1966), 3.

${ }^{9}$ D. Harold Doty and William H. Glick, "Typologies as a Unique Form of Theory Building: Toward Improved Understanding of Modelling," Academy of Management Review, 19 no. 2 (1994): 244.

${ }^{10}$ Boaz Ganor, Terrorist Organization Typologies and the Probability of a Boomerang Effect. Studies

in Conflict and Terrorism, 31 no. 4 (2008): 269-283. doi: 10.1080/10576100801925208

${ }^{11}$ Gunning (see note 5 above), 366-7.

${ }^{12}$ Khusrav Gaibulloev and Todd Sandler, "An empirical analysis of alternative ways that terrorist groups end," Public Choice, 160 no. 1-2 (2014): 25-44. doi: 10.1007/s11127-013-0136-0

${ }^{13}$ Omar A. Lizardo and Albert J. Bergesen, "Types of Terrorism by World System Location. Humboldt Journal of Social Relations, 27 (2003): 162-192.

${ }^{14}$ David C. Rapoport, "The Four Waves of Rebel Terror and September 11," Anthropoetics, 8 no. 1 (2002). Accessed 23 January, 2014: http://www.anthropoetics.ucla.edu/ap0801/terror.htm

${ }^{15}$ Earl Conteh-Morgan, (2004). Collective Political Violence: An Introduction to the Theories and Cases of Violent Conflicts, (New York: Routledge, 2004).

${ }^{16}$ Sidney G. Tarrow, Power in Movement: Social Movements and Contentious Politics, 3rd ed. (New York: Cambridge University Press, 1998), 4.

${ }^{17}$ Doug McAdam, John D. McCarthy and Mayer N. Zald, "Introduction: Opportunities, Mobilising Structures and Framing Processes - Towards a Synthetic, Comparative Perspective on Social Movements," in Comparative Perspectives on Social Movements: Political Opportunities Mobilising Structures and Cultural Framings, ed. Doug McAdam, John D. McCarthy and Mayer N. Zald (Cambridge: Cambridge University Press, 1996), 1-20.

${ }^{18}$ Charles Tilly, "Introduction," in Islamic Activism: A Social Movement Theory Approach, ed. Quintan Wiktorowicz, (Bloomington, IN: Indiana University Press, 2004), xi.

${ }^{19}$ Neil J. Smelser, Theory of Collective Behavior. (New York: Free Press, 1963), 5.

${ }^{20}$ See for example: Mohammed M. Hafez, (2003). Why Muslims Rebel: Repression and Resistance in the Muslim World. (Boulder, CO: Lynne Rienner Publishers, 2003); Quintan Wiktorowicz, "Introduction: Islamic activism and Social Movement Theory," in Islamic Activism: A Social Movement Theory Approach, ed. Quintan Wiktorowicz (Bloomington, Indiana: Indiana University Press, 2004), 1-33.

${ }^{21}$ Roel Meijer, "Review Essay: Taking the Islamist Movement Seriously: Social Movement Theory and the Islamist Movement," International Review of Social History, 50 no. 2 (2005): 279-291. doi: 10.1017/S0020859005001963, 287.

22 Jeroen Gunning, (2009). "Social Movement Theory and the Study of Terrorism," In Critical Terrorism Studies: A New Research Agenda, ed. Richard Jackson, Marie Breen Smyth and Jeroen Gunning (Oxon: Routledge, 2009), 170-71.

${ }^{23}$ Colin J. Beck, "The Contribution of Social Movement Theory to Understanding Terrorism," Sociology Compass, 2 no. 5 (2008): 1565-1581. doi: 10.1111/j.1751-9020.2008.00148.x, 1576;

${ }_{24}$ Donatella della Porta, "Introduction: On Individual Motivations in Underground Political

Organisations," in International Social Movement Research. Social Movements and Violence: 
Participation in Underground Organisations, ed. Donatella della Porta (Greenwich, CT: JAI Press, 1992), 4:5

${ }^{25}$ McAdam, et al. (see note 16 above), 1-20.

${ }^{26}$ Bob Edwards and John D. McCarthy, "Resources and Social Movement Mobilization," in The Blackwell Companion to Social Movements, ed. David A. Snow, Sarah A. Soule and Hanspeter Kriesi (Singapore: Blackwell Publishing Ltd, 2004), 116-152.

${ }^{27}$ Hanspeter Kriesi, "Political Context and Opportunity," in The Blackwell Companion to Social Movements, ed. David A. Snow, Sarah A. Soule and Hanspeter Kriesi (Singapore: Blackwell Publishers, 2004), 67-90.

${ }^{28}$ John D. McCarthy, "Conceptual origins, current problems, future directions," in Comparative Perspectives on Social Movements: Political Opportunities Mobilising

Structures and Cultural Framings, ed. Doug McAdam, John D. McCarthy and Mayer N. Zald

(Cambridge: Cambridge University Press, 1996), 27.

${ }^{29}$ Edwards and McCarthy (see note 25 above), 132-3.

${ }^{30}$ Kriesi (see note 26 above), 70.

${ }^{31}$ Ibid, 69. Analysis was informed by: Eitan Y. Alimi, "The Dialectic of Opportunities and Threats and Temporality of Contention: Evidence from the Occupied Territories," International Political Science Review, 28 no. 1 (2007): 101-123, doi: 10.1177/0192512107070405; Bader Araj, "Harsh State Repression as a Cause of Suicide Bombing: The Case of the Palestinian-Israeli Conflict," Studies in Conflict and Terrorism, 31 no. 4, (2008): 284-303, doi: 10.1080/10576100801925273; Gunning (see note 21 above); Hafez (see note 19 above); Wiktorowicz (see note 19 above).

${ }^{32}$ McCarthy (see note 27 above), 27.

${ }^{33}$ Alexander L. George, (2005). "Integrating Comparative and Within-Case Analysis: Typological Theory," in Case Studies and Theory Development in the Social Sciences, ed. Alexander L. George and Andrew Bennett (Cambridge, MA: The MIT Press, 2005). 233-263

${ }^{34}$ Audrey Kurth Cronin, How Terrorism Ends: Understanding the Decline and Demise of Terrorist Campaigns (Princeton: Princeton University Press, 2009). Dataset accessed 21 February 2013: http://howterrorismends.com/data/

${ }^{35}$ Seth G. Jones and Martin C. Libicki, How Terrorist Groups End: Lessons for Countering al-Qa'ida. (Santa Monica, CA: RAND, 2008), 141-186.

${ }^{36}$ A sustained campaign was defined, in line with Cronin, as more than one or two attacks which took place on more than one day.

${ }^{37}$ Jane's database was the primary source of qualitative data used to develop the typology. This was selected as Jane's profiles cover the years under analysis and offer a comprehensive overview of the group, its operations, background and current status offering a reliable and thoroughgoing set of data, described in a review of databases as "[e]xemplary in the field of terrorism research." Eric Price, "Library and Internet Resources for Research on Terrorism," in The Routledge Handbook of Terrorism Research, ed. Alex P. Schmid, (Chippenham: Routledge, 2011), 452.

${ }^{38}$ Louise Richardson, "State Sponsorship: A Root Cause of Terrorism?" in Root causes of terrorism: myths, realities and ways forward, ed. Tore Bjørgo (Bodmin: Routledge, 2005), 196.

${ }^{39}$ Freedom House. Freedom in the World 2012. Accessed 13 June, 2013:

http://www.freedomhouse.org/report/freedom-world/freedom-world-2012\#.UuJD62TFI18

${ }^{40}$ World Bank, Worldwide Governance Indicators. Accessed 10 July, 2013:

http://info.worldbank.org/governance/wgi/index.aspx\#countryReports

${ }^{41}$ The full set of sources is available from the author on request.

${ }^{42}$ The Hebrew University Data Analysis Package (HUDAP) software package was used to carry out the analysis; a programme designed specifically for this stable of techniques.

${ }^{43}$ Ruth Guttman and Charles W. Greenbaum, "Facet Theory: Its Development and Current Status," European Psychologist 3, no. 1 (1998): 27-31. doi: 10.1027/1016-9040.3.1.13.

${ }^{44}$ Samuel Shye, Dov Elizur and Michael Hoffman, Introduction to Facet Theory: Content Design and Intrinsic Data Analysis in Behavioural Research (Thousand Oakes, CA: Sage Publications, 1994), $32-$ 35.

${ }^{45}$ The relationship between the measures of political rights and civil liberties were investigated using Pearson product-moment correlation coefficient. There was a strong, positive correlation between the two variables $(r=.926, n=28, p<.000)$. As such, the two measures were summed and combined to create one measure for ease of interpretation.

${ }^{46}$ For more on the methodology and mathematics that supports MPOSAC see: Reuven Amar, Hudap Mathematics, (The Hebrew University of Jerusalem Computation Authority: Jerusalem, 2005); Samuel Shye, Multiple Scaling: The Theory and Application of Partial Order Scalogram Analysis, 
(Amsterdam: North-Holland, 1985); Samuel Shye "Partial Order Scalogram Analysis by Coordinates (POSAC) as a Facet Theory Measurement Procedure: How to do POSAC in Four Simple Steps," in Facet Theory and Scaling: In Search of Structure in Behavioural and Social Sciences, ed. Arie Cohen (Jerusalem: Facet Theory Association, 2007), 295-310.

${ }^{47}$ Clara Sabbagh, Erik E. Cohen and Shlomit Levy, "Styles of Social Justice Judgements as Portrayed by Partial-Order Scalogram Analysis," Acta Sociologica, 46, no. 4 (2003): 328, doi:

$10.1177 / 0001699303464004$.

${ }^{48}$ Guttman and Greenberg (see note 42 above), 25.

${ }^{49}$ David Canter "A Partial Order Scalogram Analysis of Criminal Network Structures,"

Behaviormetrika 31, no. 2 (2004): 140-144, doi: 10.2333/bhmk.31.131; Shlomit Levy and Reuven Amar, "The Use of Multidimensional Partial-Order Scalogram Analysis with Base Coordinates (MPOSAC) in Portraying a Partially-Ordered Typology of City Wards by Social-Medical Criteria," Bulletin de Méthodologie Sociologique, 65 (2000): 24-26, doi: 10.1177/075910630006500104. Item diagrams are available on request from the author.

${ }^{50}$ Reuven Amar and Erik H. Cohen, "Building Typology Through POSAC," in Facet Theory and Scaling: In Search of Structure in Behavioural and Social Sciences, ed. Arie Cohen (Jerusalem: Facet Theory Association, 2008), 311-326.

${ }^{51}$ Reuven Amar, Hudap manual, (The Hebrew University of Jerusalem Computation Authority: Jerusalem, 2005), 196-200. Accessed 11 July, 2013: http://www.facettheory.org/files/HUDAP\%20Manual.pdf

${ }^{52}$ Sabbagh, Cohen and Levy, (see note 47 above), 326.

${ }^{53}$ See for example: Erik E. Cohen, "Excellence in Educational Youth Tourism: The Case of the Israel Experience Program," (Paper presented at $24^{\text {th }}$ EuroCHRIE Congress, University of the Aegean, Thessaloniki, Greece, 2006). Accessed 23 January, 2014: http://www.bjpa.org/Publications/details.cfm?PublicationID=3624

${ }^{54}$ The scores on the political stability variable derived from World Bank measures are categorised as follows: low $=1$; $\mathrm{mid}=2-3$; high $=4$. Scores on the composite political rights/civil liberties variables drawn from Freedom House measures are categorised as: low =1-2; mid = 3-5; high = 6-7.

${ }^{55}$ Pablo San Martin, "Briefing: Western Sahara: Road to Perdition?" African Affairs 103/413, 651-660. doi: 10.1093/afraf/adh087

${ }^{56}$ Gregory Johnsen, The Last Refuge: Yemen, Al-Qaeda, and America's War on Terror. (New York: W. W. Norton \& Co., 2012).

${ }^{57}$ Ami Pedahzur, The Triumph of Israel's Radical Right. (New York: Oxford University Press, 2012), 61-80.

${ }^{58}$ Communist Party of Nepal-Maoist. (2008). In Jane's World Insurgency and Terrorism (Vol. 28, pp. 350-356). (Surrey: Jane's Information Group, 2008).

${ }^{59}$ Katherine Barbieri and Omar Keshk. Correlates of War Project Trade Data Set Codebook, Version 3.0, 2012. Accessed 23 November, 2013: http://correlatesofwar.org.

${ }^{60}$ United States Army, Field Manual 100-20: Military Operations in Low Intensity Conflict, (Washington D.C.: U.S. Government Printing Office, 1990), 1. Accessed 23 November, 2013: http://www.gwu.edu/ nsarchiv/NSAEBB/NSAEBB63/doc4.pdf.

${ }^{61}$ Ekaterina Stepanova, Terrorism in Asymmetrical Conflict: Ideological and Structural Aspects. (SIPRI Research Report No. 23. Oxford University Press, 2008), 9-11.

62 Ibid.

${ }^{63}$ Jackson (see note 5 above), 6.

${ }^{64}$ Tore Bjørgo, "Introduction," in Root Causes of Terrorism, ed. Tore Bjørgo (Bodmin, Cornwall: Routledge, 2005), 2.

${ }^{65}$ James M. Lutz and Brenda J. Lutz, "Democracy and Terrorism," Perspectives on Terrorism 4, no.1 (2010): 63-74.

${ }^{66}$ Max Abrahms, "The Political Effectiveness of Terrorism Revisited," Comparative Political Studies 45, no.3 (2012): 366-393. doi: 10.1177/0010414011433104.

${ }^{67}$ Max Taylor. "Is Terrorism a Group Phenomenon?" Aggression and Violent Behavior 15, no. 2 (2011): 121-129. doi: 10.1016/j.avb.2009.09.001. 